\title{
Near-Surface Frontogenesis and Atmospheric Instability along the U.S. East Coast during the Extratropical Transition of Hurricane Matthew (2016)
}

\author{
SCOTT W. POWELL \\ Department of Meteorology, Naval Postgraduate School, Monterey, California \\ Michael M. BELL \\ Department of Atmospheric Science, Colorado State University, Fort Collins, Colorado
}

(Manuscript received 16 March 2018, in final form 30 November 2018)

\begin{abstract}
Hurricane Matthew locally generated more than $400 \mathrm{~mm}$ of rainfall on 8-9 October 2016 over the eastern Carolinas and Virginia as it transitioned into an extratropical cyclone. The heaviest precipitation occurred along a swath situated up to $100-200 \mathrm{~km}$ inland from the coast and collocated with enhanced low-tropospheric frontogenesis. Analyses from version 3 of the Rapid Refresh (RAPv3) model indicate that rapid frontogenesis occurred over eastern North and South Carolina and Virginia on 8 October, largely over a 12-h time period between 1200 UTC 8 October and 0000 UTC 9 October. The heaviest rainfall in Matthew occurred when and where spiral rainbands intersected the near-surface front, which promoted the lift of conditionally unstable, moist air. Parallel to the spiral rainbands, conditionally unstable low-tropospheric warm, moist oceanic air was advected inland, and the instability was apparently released as the warm air mass rose over the front. Precipitation in the spiral rainbands intensified on 9 October as the temperature gradient along the near-surface front rapidly increased. Unlike in Hurricane Floyd over the mid-Atlantic states, rainfall totals within the spiral rainbands of Matthew as they approached the near-surface front evidently were not enhanced by release of conditional symmetric instability. However, conditional symmetric instability release in the midtroposphere may have enhanced rainfall $200 \mathrm{~km}$ northwest of the near-surface front. Finally, although weak cold-air damming occurred prior to heavy rainfall, damming dissipated prior to frontogenesis and did not impact rainfall totals.
\end{abstract}

\section{Introduction}

Inland flooding caused by heavy rainfall frequently inflicts property damage and human casualties in the United States during landfalling tropical cyclones. Over the past several decades, model prediction of extreme rainfall associated with tropical cyclones has improved, but precisely forecasting the locations of heaviest rainfall remains challenging. Hurricane Matthew (2016) was one recent example of an extreme rainfall event over the U.S. East Coast associated with a tropical cyclone. A total of 24 people died in North Carolina (NC) and South Carolina (SC) as a result of freshwater flooding during Matthew (Stewart 2017). Matthew tracked northward out of the Caribbean Sea and closely paralleled the southeastern U.S. coast from 7 to 9 October 2016. It briefly made landfall in northeastern SC on 8 October as a tropical

Corresponding author: Scott W. Powell, scott.powell@nps.edu cyclone undergoing extratropical transition (Jones et al. 2003; Evans et al. 2017). The center then moved northeastward along the coast of the Carolinas while the heaviest rainfall associated with the cyclone persisted 100-200 km inland (Stewart 2017). The storm was declared post-tropical operationally at 0900 UTC 9 October. Figure 1 illustrates the best track and minimum pressure for Matthew.

Over $400 \mathrm{~mm}(\sim 15.75 \mathrm{in}$.) of rain fell over parts of eastern SC, NC, and Virginia (VA) during a 24-h-long period on 8-9 October, and over $100 \mathrm{~mm}$ of precipitation occurred over a much broader region within each state (Stewart 2017). As a result, significant flooding occurred during and days after the storm along North Carolinian rivers. The flooding was preceded by a rainy September, which included up to about $250 \mathrm{~mm}$ ( $\sim 10$ in.) of precipitation that occurred during the passage of Tropical Storm Hermine on 1-2 September. The largest rain totals were focused along a path near where 

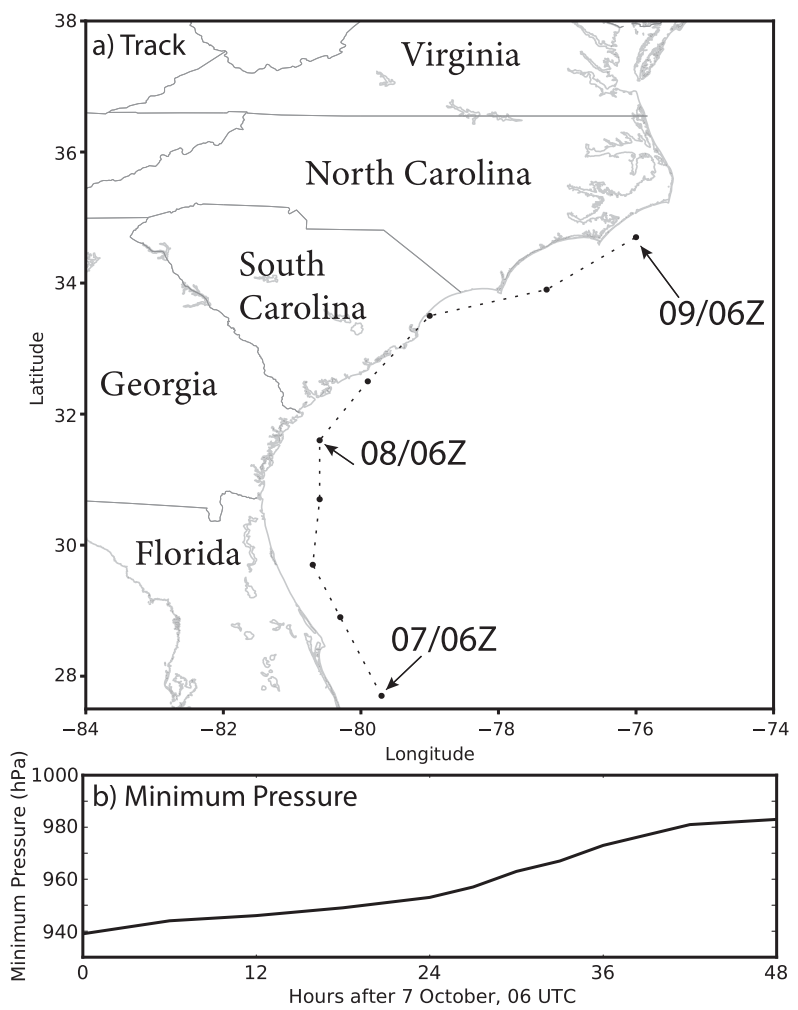

FIG. 1. (a) Track of Hurricane Matthew in the National Hurricane Center best track. Dots represent a new position every $6 \mathrm{~h}$, and position at 0600 UTC 7-9 Oct is denoted with arrows. (b) Estimated minimum surface pressure of Hurricane Matthew in the best track.

the National Weather Service identified a "quasi-stationary coastal front" in operational analysis (NOAA 2018a).

In terms of extreme precipitation that occurred, particularly over NC, the closest recorded analog to Matthew is perhaps Hurricane Floyd, which directly impacted NC on 15-16 September 1999 before transitioning into an extratropical cyclone and exhibiting a similar west-of-track maximum in precipitation that caused extensive flooding along a large swath of the U.S. East Coast. Atallah and Bosart (2003) explored the spatial precipitation distribution during Floyd in detail with particular emphasis on the synoptic-scale forcing that led to the extreme rainfall. They found that extreme precipitation coincided with strong isentropic ascent occurring along a deep coastal baroclinic zone between a cold core potential vorticity (PV) anomaly associated with an approaching midlatitude trough and the warm core PV anomaly associated with Floyd. Within an environment supportive of synoptic-scale ascent, the baroclinic zone appeared to focus the most intense precipitation along a convergence boundary near a surface front. When examining 32 tropical cyclones that made landfall along the U.S. East Coast between 1950 and 1998, Atallah et al. (2007) reached similar conclusions about the synoptic-scale forcing common to extreme rain events in tropical cyclones. They found also that leftof-track precipitation distributions like those experienced during Matthew occur frequently when a tropical cyclone interacts strongly with a midlatitude trough located within $1500 \mathrm{~km}$ to the northwest, and that positively tilted troughs are ideal for extension of a baroclinic zone from the west to north quadrants of a transitioning cyclone.

In a modeling study of the extratropical transition of Floyd, Colle (2003) found that "strong frontogenesis as well as moist symmetric instability below $800 \mathrm{mb}$ and neutrality aloft resulted in a narrow and intense band of precipitation just inland of the coast" (p. 2924). Consistent with Atallah and Bosart (2003), he found that diabatic heating helped drive frontogenesis because the greatest latent heat release at midlevels occurred on the warm side of the developing front. The extensive flooding during Floyd was not well predicted, and this was ultimately attributed to the combination of processes involved in forcing the band of heavy precipitation, and in particular, the failure of models to properly represent latent heating. In contrast, the threat of large inland precipitation amounts was better predicted in advance of Matthew. Over $24 \mathrm{~h}$ in advance, between $203 \mathrm{~mm}$ ( $8 \mathrm{in}$.) and $305 \mathrm{~mm}$ (12 in.) of rainfall, with local amounts over $381 \mathrm{~mm}$ (15in.), were predicted for a swath in eastern NC closely matching the eventual location of the precipitation (NOAA 2018b). Nonetheless, the banded precipitation pattern ultimately observed (section 3) was not explicitly predicted, and rainfall in northeastern $\mathrm{NC}$ and southeastern VA was consistently underpredicted on 7-8 October prior to the onset of precipitation there.

Although our understanding of synoptic-scale processes that support development of swaths of heavy rainfall during events such as Floyd or Matthew has improved, questions remain about regional-scale and mesoscale processes that might impact the location and intensity of rainfall. For example, Bosart and Dean (1991) and Atallah and Bosart (2003) suggested that cold-air damming east of the Appalachian Mountains accompanies heavy precipitation as a cyclone undergoes extratropical transition. They did not quantify the potential effect of cold-air damming on precipitation, but they acknowledged that it was of secondary importance to other processes that encourage intense rainfall accompanying a cyclone undergoing extratropical transition. Damming is common when surface pressures are higher over New England than over the southeastern United States. The pressure gradient force moves air southward parallel to the Appalachians, and the cool low-level air becomes trapped on the east side of the mountains (Bell and Bosart 1988). Meanwhile, as a tropical cyclone approaches the East Coast, it advects 
warm, moist air inland around its northeastern quadrant. Where it meets cooler, drier air over land, a coastal front develops; the temperature gradient along such a front could be enhanced if accompanied by cold-air damming (Croke 2005). Atallah et al. (2007) noted that left-of-track precipitation distributions can occur without cold-air damming, even though such distributions are common in particular for tropical cyclones moving up the East Coast where cold-air damming might occur. Colle (2003) claimed that terrain did not affect the precipitation distribution in Floyd; however, his model simulations were focused farther north from New Jersey to Connecticut, where the mountains are shorter and closer to the coast than in the Carolinas and Virginia. Also, Garcia-Rivera et al. (2016) concluded that the Appalachian Mountains and cold-air damming did not impact precipitation during a much weaker Tropical Storm Kyle over NC in 2002.

As Matthew moved northward along the U.S. East Coast, radar data, which will be analyzed later in this article (section 4), indicated that the most intense rainfall at a given time was confined to narrow regions along the inland portions of spiral rainbands rotating around the cyclone. The study of Colle (2003) discussed the importance of frontogenesis, moisture advection and convergence, and release of conditional symmetric instability in supporting extremely intense rainfall. This study investigates in what ways the combined effects of cold-air damming, frontogenesis, moisture convergence, and atmospheric instability influenced the production of large rainfall totals during Hurricane Matthew. Specifically, we will address the following questions:

1) Could cold-air damming induced by the Appalachian Mountains, which were approximately $300 \mathrm{~km}$ away from the locations of the largest rainfall totals in Matthew, have enhanced rainfall in eastern SC, NC, and VA (section 3)?

2) What was the spatial distribution of frontogenesis over eastern NC on 8 October (section 4)?

3) Did conditional symmetric instability enhance rainfall during Matthew (section 5)?

First, we will briefly demonstrate that synoptic-scale conditions were consistent with those associated with left-of-track precipitation maxima described by Atallah et al. (2007).

\section{Operational analysis and data}

To characterize the synoptic-scale environment in place during Matthew (section 3), we used hourly analysis from version 3 of the operational Rapid Refresh (RAPv3; Benjamin et al. 2016) model. RAPv3 has approximately 13-km horizontal grid spacing and 51 vertical levels with a model top at $10 \mathrm{hPa}$. The analysis used herein has vertical grid spacing of $25 \mathrm{hPa}$. It assimilates a variety of groundbased, satellite-based, aircraft, and rawinsonde observations to generate its analyses, including observations of radar reflectivity and Doppler velocity from the Weather Surveillance Radar-1988 Doppler (WSR-88D) network. Some reflectivity observations from WSR-88D are shown in section 4 . Specifically, data from radars serving the Columbia, SC (KCAE); Charleston, SC (KCLX); Wilmington, NC (KLTX); Raleigh, NC (KRAX); Newport/ Morehead City, NC (KMHX); Blacksburg, VA (KFCX); and Wakefield, VA (KAKQ) forecast offices were used. The radar data were interpolated to a rectilinear grid with horizontal grid spacing of $1 \mathrm{~km}$ and vertical grid spacing of $500 \mathrm{~m}$.

Surface station data were also utilized to determine whether and when cold-air damming occurred in SC, NC, or VA. An objective algorithm for cold-air damming detection, which is described by Bailey et al. (2003), was applied to mean sea level pressure estimates over the Carolinas and Virginia. The stations used by this algorithm are mapped in Fig. 2; the results are discussed in section 3 .

\section{Synoptic-scale environment and rainfall observations}

Figure 3 shows the evolution of 500-hPa geopotential height (black contours in decameters) on 7-9 October. At 0000 UTC 7 October $^{1}$ (Fig. 3a), a long-wave trough axis was present west of $100^{\circ} \mathrm{W}$ while Matthew was centered off the south Florida coast. By 0000 UTC 8 October (Fig. 3c), the long-wave trough axis was located between $90^{\circ}$ and $95^{\circ} \mathrm{W}$. During the earlier half of 8 October (Figs. 3c,d), the midlatitude long-wave trough moving eastward across the United States temporarily became more negatively tilted. However, as Matthew moved offshore North Carolina, the trough developed a positive tilt (Fig. 3e). As mentioned in section 1, the positive tilt is favorable for the formation of a baroclinic zone to the north of the cyclone. Gray contours in Fig. 3 depict mean sea level pressure (MSLP) in hPa. At 0000 UTC 7 October, an eastward-moving surface high pressure was located near $45^{\circ} \mathrm{N}, 75^{\circ} \mathrm{W}$, so that the pressure gradient along the U.S. East Coast was generally oriented from northeast to southwest on 7-9 October, a prerequisite for cold-air damming. From 0000 UTC 7 October (Fig. 3a) to 0000 UTC 8 October (Fig. 3c), a

\footnotetext{
${ }^{1}$ In figures, the convention XX/YY UTC in which XX = day of month and $\mathrm{YY}=$ hour will be used to denote dates and times.
} 


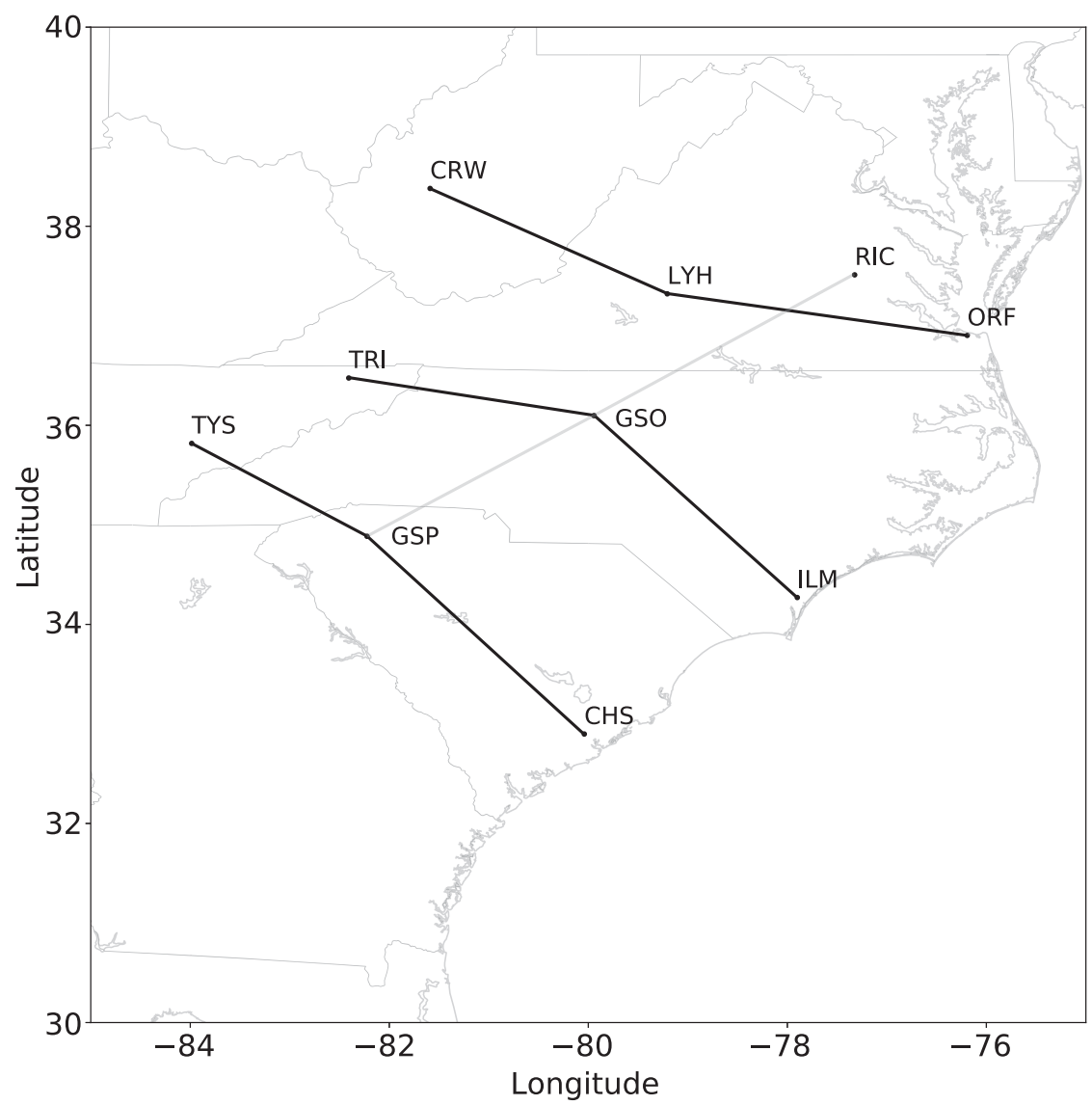

FIG. 2. Outline of surface weather stations used in cold-air damming detection algorithm.

Figure is a recreation of Fig. 3 from Bailey et al. (2003).

weakening surface pressure ridge was present east of the Appalachians.

Figure 4 includes three quantities computed from RAP at $950 \mathrm{hPa}$ : frontogenesis $\left(\mathrm{K} 100 \mathrm{~km}^{-1} 3 \mathrm{~h}^{-1}\right.$; shading), potential temperature $\theta$ (K; black lines), and horizontal wind $\left(\mathrm{m} \mathrm{s}^{-1}\right.$; vectors) analyzed by RAP every $6 \mathrm{~h}$ from 0000 UTC 7 October to 0000 UTC 9 October. The black dashed line represents the 298-K $\theta$ contour, and the $\theta$ contour interval is $2 \mathrm{~K}$. Frontogenesis $F$ is a diagnostic quantity defined as the Lagrangian derivative of the horizontal temperature $(T)$ gradient:

$$
F=\frac{d}{d t}\left|\nabla_{h} \theta\right|
$$

in which

$$
\frac{d}{d t}=\frac{\partial}{\partial t}+u \frac{\partial}{\partial x}+v \frac{\partial}{\partial y}+w \frac{\partial}{\partial z},
$$

and $u, v$, and $w$ represent, respectively, zonal, meridional, and vertical wind; and the subscript $h$ refers to a horizontal gradient. In this article, $F$ is approximated by the Petterssen frontogenesis (Petterssen 1936). It includes the effects of deformation and divergence on formation/destruction of temperature gradients:

$$
\begin{aligned}
F \approx & -\frac{1}{\left|\nabla_{h} \theta\right|}\left\{\left[\left(\frac{\partial \theta}{\partial x}\right)^{2} \frac{\partial u}{\partial x}+\left(\frac{\partial \theta}{\partial y}\right)^{2} \frac{\partial v}{\partial y}\right]\right. \\
& \left.+\left[\frac{\partial \theta}{\partial x} \frac{\partial \theta}{\partial y}\left(\frac{\partial v}{\partial x}+\frac{\partial u}{\partial y}\right)\right]\right\} .
\end{aligned}
$$

Partial derivatives in Eq. (2) were computed using firstordered centered differencing in space. Convergence of $\theta$ gradients played a negligible role in frontogenesis (not shown).

Early on 7 October, a wedge of cool $(\theta=294-296 \mathrm{~K})$ air located inland over SC and NC moved westward toward the mountains (Figs. 4a-c). As Matthew approached on 8 October, the cool air moved back toward the east as it simultaneously wrapped around the western and southern sides of the cyclone. The temperature field and ridge east of the mountains suggest that at least weak cold-air damming took place during 7-8 October 

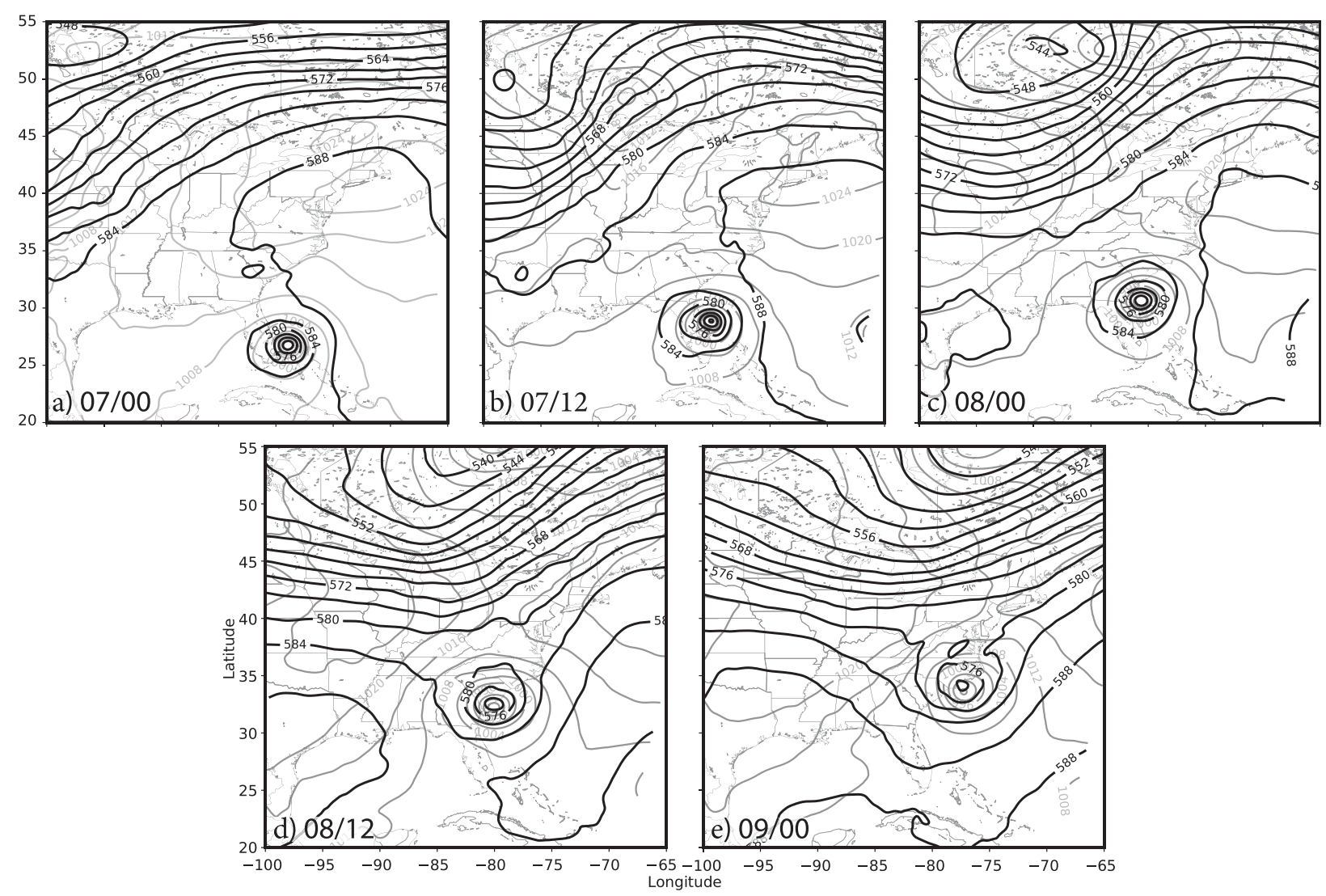

FIG. 3. 500-hPa geopotential height (dam; black contours) and mean sea level pressure (hPa; gray contours) over the eastern United States and western Atlantic from RAP analysis every $12 \mathrm{~h}$ from (a) 0000 UTC 7 Oct to (e) 0000 UTC 9 Oct.

(Bell and Bosart 1988; Lackmann and Stanton 2004; Rackley and Knox 2016). An objective algorithm for coldair damming detection applied to mean sea level pressure estimates over the Carolinas and Virginia (Bailey et al. 2003) also indicates that weak cold-air damming took place between 0000 UTC 7 October and 0600 UTC 8 October. Mean sea level pressures from 0000 UTC 7 October to 0000 UTC 9 October at the stations shown in Fig. 2 are listed in Table 1. All conditions required by Bailey et al. (2003) for possible cold-air damming were met between 0000 UTC 7 October and 0600 UTC 8 October; however, we did not require the Laplacian of MSLP along each black segment in Fig. 2 to exceed any value. After 0600 UTC 8 October, MSLP in the central portions of VA, NC, and SC (respectively at LYH, GSO, and GSP) were continually less than MSLP farther inland (CRW, TRI, and TYS), meaning that cold-air damming was no longer occurring. Since almost all of the frontogenesis occurred and precipitation fell after 0600 UTC 8 October over eastern $\mathrm{NC}$ and VA, cold-air damming did not significantly impact rainfall totals.

At 1200 UTC 8 October (Fig. 4g), a southwest-northeastoriented frontal boundary extending from near the center of Matthew was apparent in eastern SC. At that time, the analyzed $950-\mathrm{hPa}$ potential temperature near $36^{\circ} \mathrm{N}, 79^{\circ} \mathrm{W}$ (near Durham, NC) was 295-296K, and near $34.5^{\circ} \mathrm{N}$, $77.5^{\circ} \mathrm{W}$ (between Jacksonville and Wilmington, NC), it was 299-300 K. By 1800 UTC (Fig. 4h), a clear surface frontal boundary was present, and values of frontogenesis ex-

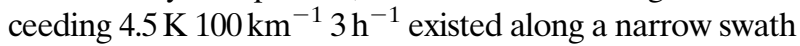
extending to southeastern VA. The temperature remained similar near the coast compared to at 1200 UTC but had dropped by about $1-3 \mathrm{~K}$ over central NC. The frontal boundary progressed northeastward with the maximum temperature gradient located near the coast of $\mathrm{NC}$ by 0000 UTC 9 October (Fig. 4i). Frontogenesis by that time

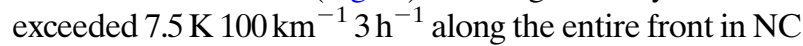
and VA.

Figure 5a depicts estimated rainfall amounts over northeastern SC, eastern NC, and southern VA derived from radar and rain gauge ${ }^{2}$ in the NCEP stage IV precipitation dataset. Offshore data does not exist in this

\footnotetext{
${ }^{2}$ Estimates were obtained from the National Weather Service at http://water.weather.gov/precip/download.php.
} 

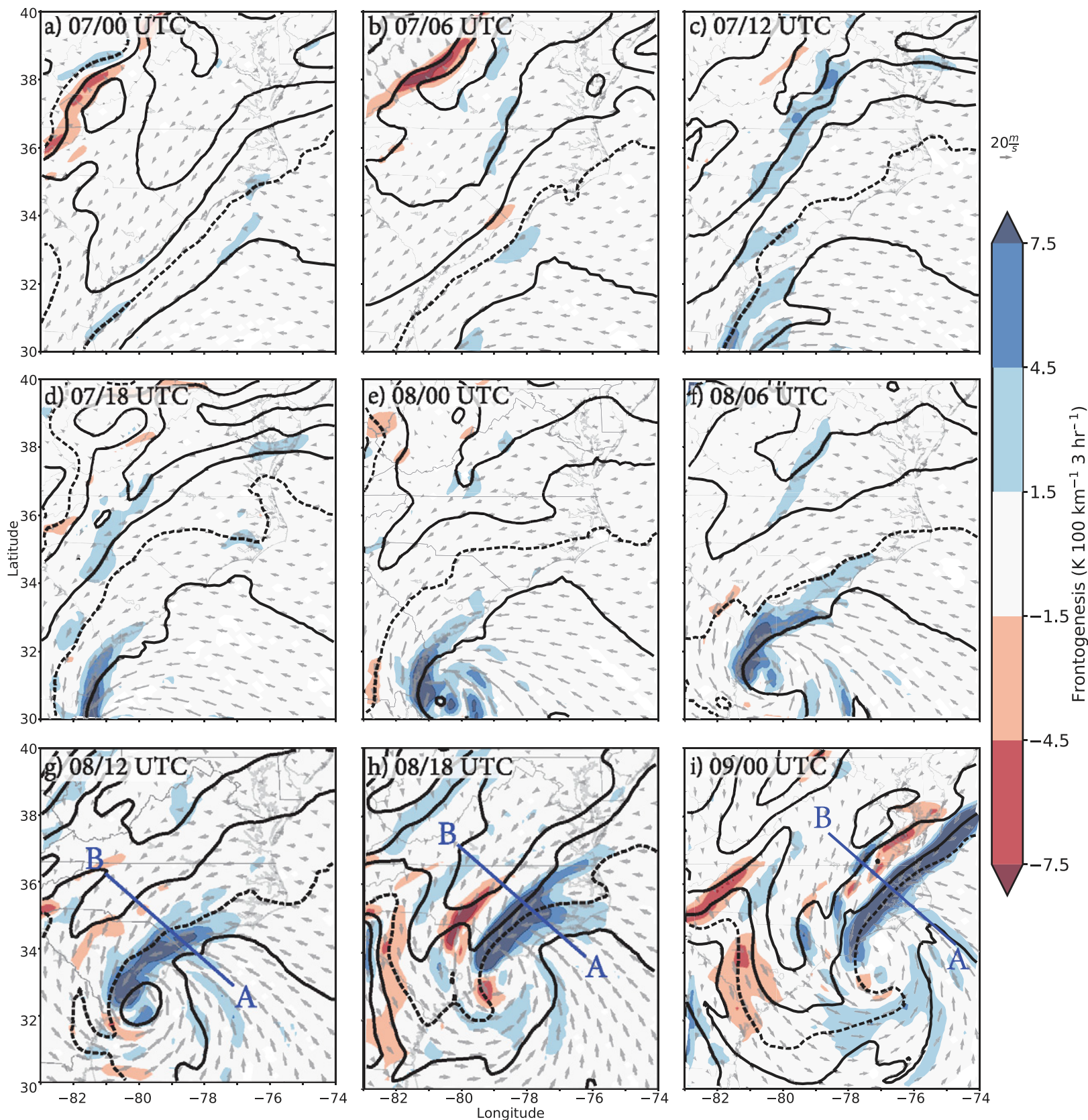

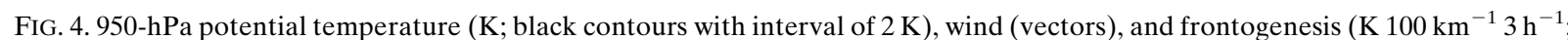
shaded) from RAP analysis every $6 \mathrm{~h}$ over the southeastern United States from (a) 0000 UTC 7 Oct to (i) 0000 UTC 9 Oct. The dashed black line represents the $298-\mathrm{K}$ potential temperature isotherm. In (g)-(i), solid blue lines and letters " $A$ " and "B" denote cross sections illustrated by Fig. 8 .

dataset. The largest rainfall amounts occurred inland along a swath located along a line from about $34^{\circ} \mathrm{N}, 79.5^{\circ} \mathrm{W}$ to $36^{\circ} \mathrm{N}, 78^{\circ} \mathrm{W}$ then east-northeastward toward southeastern Virginia near $37^{\circ} \mathrm{N}, 76^{\circ} \mathrm{W}$. Some individual streaks of enhanced precipitation extended from southeast to northwest into and through the swath of highest amounts; as shown in section 4 , these were likely associated with convective cells that were focused along spiral rainbands that moved inland. Figure $5 b$ shows the frequency of rainfall (defined by detection of $>7 \mathrm{dBZ}$ echo by WSR-88D) on 8-9 October. The greatest frequency of rainfall $(60 \%+$ of the time) included the region where the precipitation maximum was located but also extensive areas farther inland where smaller rainfall totals occurred. Thus, the 
TABLE 1. Mean sea level pressure (hPa) at Automated Surface Observing Systems (ASOS) stations used for Bailey et al. (2003) cold-air damming detection algorithm.

\begin{tabular}{|c|c|c|c|c|c|c|c|c|c|}
\hline Station/time & $\begin{array}{c}0000 \mathrm{UTC} \\
7 \mathrm{Oct}\end{array}$ & $\begin{array}{c}0600 \text { UTC } \\
7 \text { Oct }\end{array}$ & $\begin{array}{c}1200 \mathrm{UTC} \\
7 \mathrm{Oct}\end{array}$ & $\begin{array}{c}1800 \mathrm{UTC} \\
7 \mathrm{Oct}\end{array}$ & $\begin{array}{c}0000 \text { UTC } \\
8 \text { Oct }\end{array}$ & $\begin{array}{c}0600 \text { UTC } \\
8 \text { Oct }\end{array}$ & $\begin{array}{c}1200 \text { UTC } \\
8 \text { Oct }\end{array}$ & $\begin{array}{l}1800 \mathrm{UTC} \\
8 \mathrm{Oct}\end{array}$ & $\begin{array}{c}0000 \text { UTC } \\
9 \text { Oct }\end{array}$ \\
\hline CRW & 1022.0 & 1020.3 & 1021.1 & 1019.3 & 1017.8 & 1016.6 & 1016.8 & 1017.3 & 1020.4 \\
\hline LYH & 1024.6 & 1022.8 & 1022.0 & 1021.3 & 1019.3 & 1017.6 & 1015.9 & 1013.6 & 1013.3 \\
\hline ORF & 1022.3 & 1021.0 & 1020.8 & 1020.0 & 1018.5 & 1016.2 & 1014.0 & 1009.3 & 1005.1 \\
\hline RIC & 1024.3 & 1022.8 & 1022.5 & 1020.9 & 1019.7 & 1017.8 & 1015.9 & 1012.8 & 1011.6 \\
\hline TRI & 1020.4 & 1018.7 & 1019.1 & 1017.0 & 1015.8 & 1013.8 & 1013.4 & 1012.2 & 1017.7 \\
\hline GSO & 1022.0 & 1020.0 & 1018.9 & 1018.2 & 1016.2 & 1014.5 & 1011.4 & 1008.8 & 1009.4 \\
\hline ILM & 1017.8 & 1016.1 & 1015.7 & 1014.7 & 1012.5 & 1009.4 & 1001.7 & 994.1 & 992.7 \\
\hline TYS & 1018.5 & 1017.0 & 1019.0 & 1015.9 & 1014.8 & 1013.9 & 1013.9 & 1014.6 & 1018.3 \\
\hline GSP & 1020.4 & 1018.6 & 1017.4 & 1016.2 & 1013.8 & 1011.7 & 1008.1 & 1007.9 & 1011.8 \\
\hline CHS & 1016.7 & 1014.7 & 1012.7 & 1010.1 & 1004.5 & 995.8 & 984.1 & 996.2 & 1007.3 \\
\hline
\end{tabular}

swath of large rainfall totals in eastern $\mathrm{NC}$ are present not simply because rainfall occurred for a longer time, but rather the precipitation there was more intense.

\section{Radar echoes and frontogenesis over NC}

Figure 6 shows observed reflectivity from WSR-88D at approximately $2.5 \mathrm{~km}$ above sea level every $3 \mathrm{~h}$ from 1200 UTC 8 October to 0300 UTC 9 October. The black contour outlines an area where $F$ exceeded $1.5 \mathrm{~K}$ $100 \mathrm{~km}^{-1} 3 \mathrm{~h}^{-1}$ (blue shading in Fig. 4), and vectors indicate horizontal wind at $950 \mathrm{hPa}$. At 1200 UTC 8 October, a region of intense rainfall with reflectivity exceeding $35 \mathrm{dBZ}$ was observed in southern $\mathrm{NC}$ and northeastern SC and was generally confined to regions close to where Matthew's spiral rainbands were located. The high reflectivity was mostly surrounded by the $1.5 \mathrm{~K}$ $100 \mathrm{~km}^{-1} 3 \mathrm{~h}^{-1}$ of $F$. Intense rainfall, while embedded within a broad stratiform region consisting of weaker rainfall, moved northeastward through $\mathrm{NC}$ over the next several hours. Generally, the most intense convective cells were located within discrete spiral tropical rainbands that were oriented from southeast to northwest.

As convective cells over the ocean moved inland, they typically became more intense, and by 1800 UTC, echoes with reflectivity exceeding $45 \mathrm{dBZ}$ over eastern $\mathrm{NC}$ were not infrequent-particularly near $35.5^{\circ} \mathrm{N}, 78^{\circ} \mathrm{W}$ (Fig. 6c). By this time, intense $35+\mathrm{dB} Z$ echoes were not confined to inland spiral rainbands but were also found along and just inland of a developing frontal boundary (Fig. 4h) over eastern NC. By 2100 UTC, a principal spiral rainband extended inland from Cape Lookout $\left(34.6^{\circ} \mathrm{N}\right.$, $\left.76.5^{\circ} \mathrm{W}\right)$. Intense precipitation was then located well northeastward of the spiral rainbands along a line extending to the Chesapeake Bay from about $35.5^{\circ} \mathrm{N}, 78^{\circ} \mathrm{W}$, or centered along the western edge of the $1.5 \mathrm{~K} 100 \mathrm{~km}^{-1}$ $3 \mathrm{~h}^{-1} F$ contour. The inland part of the spiral rainband intensified as it moved northeastward across eastern and northeastern North Carolina by 0000-0300 UTC 9 October; some radar echoes then exceeded $50 \mathrm{~dB} Z$ over the coastal regions of northeastern NC and southeastern VA. Particularly over eastern NC, when comparing the distribution of rainfall (Fig. 5a) with radar echoes, the largest rainfall amounts appear to be oriented in streaks that probably correspond to the orientations of northeastward-moving rainbands when they were most intense. The spiral rainbands seen in Fig. 6 appear to have sometimes corresponded with locations of frontogenesis extending offshore.

Additionally, a secondary region of $35+\mathrm{dB} Z$ echoes developed over central NC and VA about $200 \mathrm{~km}$ inland from the region of primary frontogenesis around 1500 UTC and moved northeastward. At 1500 UTC, this area of heavy rainfall was centered near $36^{\circ} \mathrm{N}, 80.5^{\circ} \mathrm{W}$ (Fig. 6b), and a small region of $F$ exceeding $1.5 \mathrm{~K} 100 \mathrm{~km}$ $3 \mathrm{~h}^{-1}$ existed in its vicinity through $0000 \mathrm{UTC}$, and is described in more detail below. The rainfall totals associated with this precipitation (Fig. 5a) were not as large as those along the near-surface front associated with the great rain totals, but the period of heavy rain farther inland than the main front probably also contributed to high river levels on the coastal plain in the days following Matthew.

Figure 7, which is similar to Fig. 4, provides a magnified view of $950 \mathrm{hPa} F, \theta$ (with $1-\mathrm{K}$ contours), and wind at higher temporal resolution. The inland part of the principal spiral rainband seen in Fig. 6 was located near confluent low-level flow, and the largest values of $F$ corresponded to areas of maximum confluence. At 1200-1800 UTC, the axis of confluence along which frontogenesis occurred became more zonally oriented with increasing latitude. For example, at 1800 UTC (Fig. 7c), maximum $F$ was generally oriented from southwest to northeast south of $35^{\circ} \mathrm{N}$. North of $35^{\circ} \mathrm{N}$, two separate areas of large $F$ were present. One continued northeastward into far southeastern VA. The other extended toward the east to about $76^{\circ} \mathrm{W}$. By $0000 \mathrm{UTC}$, 


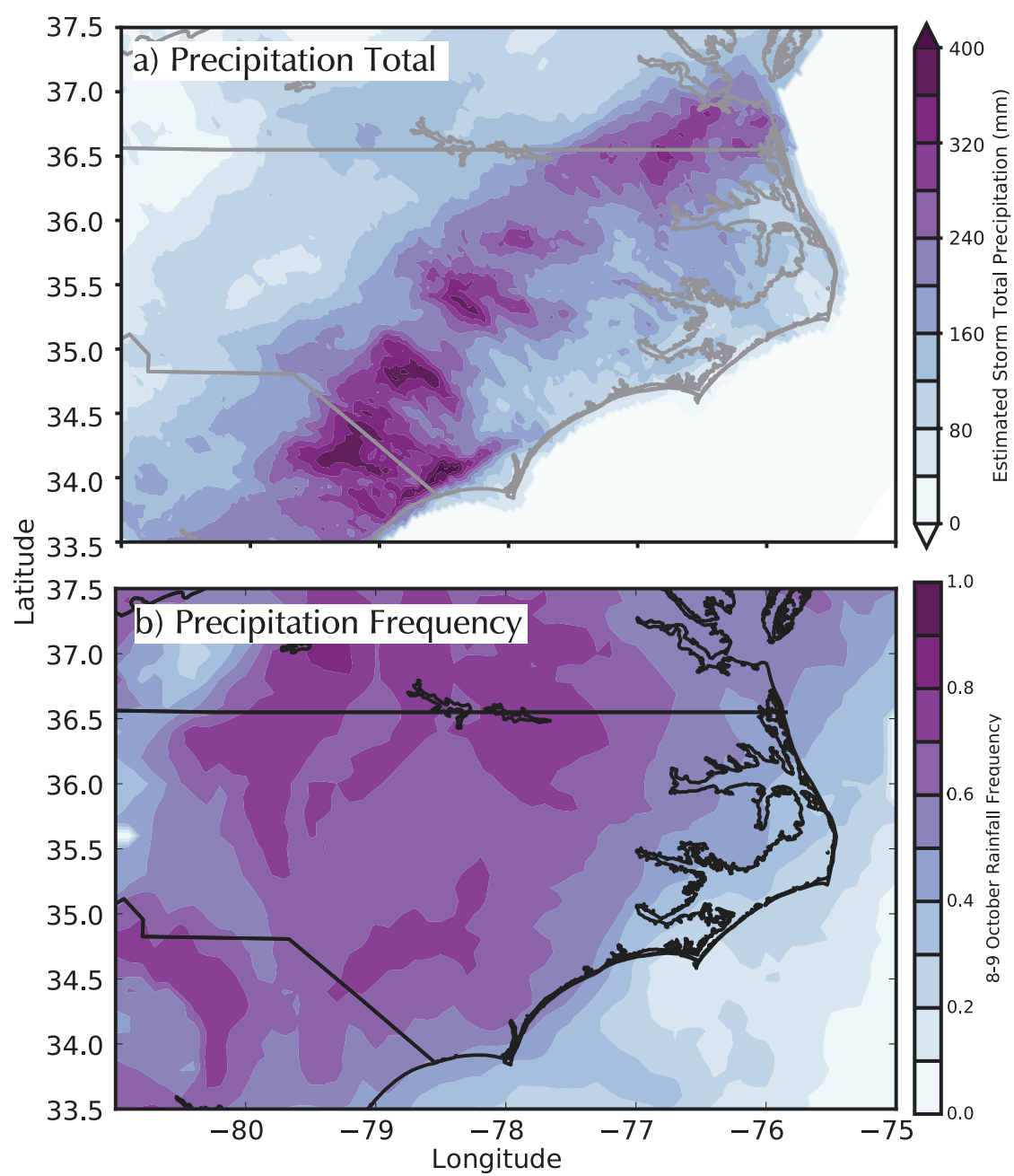

FIG. 5. (a) Estimated total precipitation on 8-9 Oct derived from radar and rain gauge data using the NCEP stage IV precipitation dataset. (b) Fraction of time on 8-9 Oct during which rain detected by radar occurred.

the axis of maximum $F$ was contained within a single long region extending from southwest to northeast throughout eastern NC, VA, and offshore (Fig. 4i). Where the axis of confluent flow was oriented from southwest to northeast, $\sim 15-20 \mathrm{~m} \mathrm{~s}^{-1}$ northeasterly wind was situated between stronger easterly, warm, and moist wind to its east and north-northeasterly, colder, and drier flow to its west. The zonally oriented frontogenesis (that along $35^{\circ} \mathrm{N}$ at 1800 UTC) was weaker than frontogenesis farther inland, but it apparently contributed to tightening the temperature gradient over eastern $\mathrm{NC}$ before air there was advected toward the front. For example, near $35^{\circ} \mathrm{N}, 77^{\circ} \mathrm{W}$ (inland from the Pamlico Sound), the 298- and 299-K $\theta$ contours were separated meridionally along $77^{\circ} \mathrm{W}$ by approximately $74 \mathrm{~km}$ at 1200 UTC. Frontogenesis occurred between 1500 and 1800 UTC, and by 1800 UTC, the two contours were separated meridionally by only $42 \mathrm{~km}$.
During the entire time period displayed in Fig. 7, the temperature gradient along the near-surface front mostly increased to the west of the $298-\mathrm{K}$ contour, which is where most of the $35+\mathrm{dBZ}$ echo was located. Another secondary region of low-level frontogenesis was also present to the northwest and west of the near-surface front. It was located near $78^{\circ} \mathrm{W}$ somewhere between $35.5^{\circ} \mathrm{N}$ and north of $37.5^{\circ} \mathrm{N}$ at 1500,2100 , and $0000 \mathrm{UTC}$, or in the vicinity of the secondary region of $35+\mathrm{dBZ}$ echo that was located over central NC and VA and described above (Figs. 6b-d). Magnitudes of $F$ in this region exceeded $7.5 \mathrm{~K} 100 \mathrm{~km}^{-1} 3 \mathrm{~h}^{-1}$ at 2100 and 0000 UTC. By 0300 UTC, the temperature gradient formed by this secondary area of low-level frontogenesis had merged with the near-surface front near the coasts of NC and VA. The increasing temperature gradient along the near-surface front probably aided development of $45+\mathrm{dBZ}$ radar echoes along the 


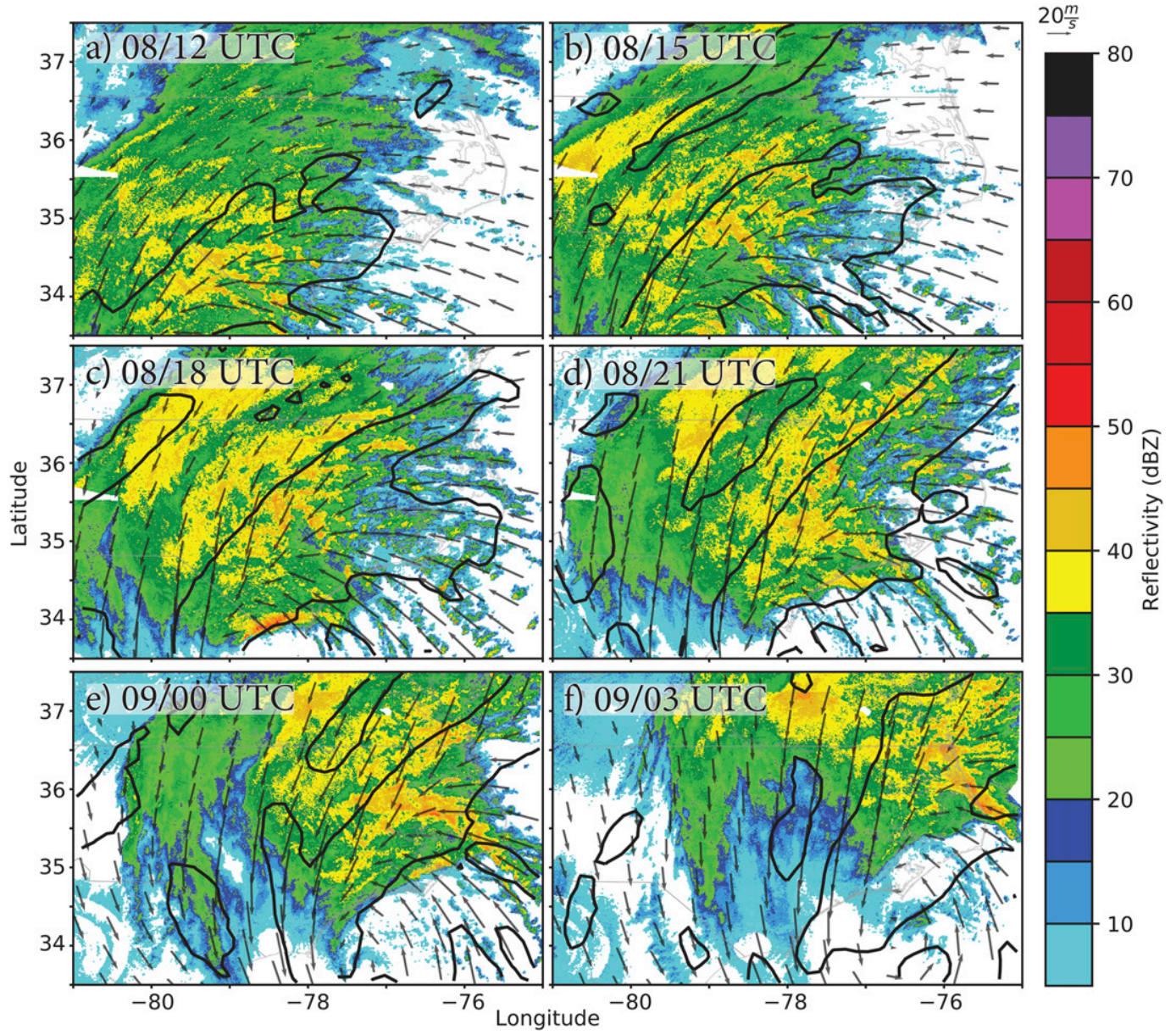

FIG. 6. Observed radar reflectivity (dBZ; shaded) from WSR-88D at $2.5 \mathrm{~km}$ above sea level and 950-hPa wind (vectors) every $3 \mathrm{~h}$ from (a) 1200 UTC 8 Oct to (f) 0300 UTC 9 Oct. The black contour outlines 950-hPa frontogenesis greater than $1.5 \mathrm{~K} 100 \mathrm{~km}^{-1} 3 \mathrm{~h}^{-1}$.

principal spiral rainband after 1800 UTC in northeastern $\mathrm{NC}$ and southeastern VA.

Figure 8 includes three representative cross sections of moisture convergence $\left(\mathrm{g} \mathrm{kg}^{-1} \mathrm{~h}^{-1}\right.$; shading), saturated equivalent potential temperature $\theta_{\mathrm{es}}$ (contours with interval of $2 \mathrm{~K}$ ), and wind (vectors) - at 1200 and 1800 UTC 8 October and at 0000 UTC 9 October. Moisture convergence is defined as

$$
q_{\mathrm{conv}}=-\mathbf{V}_{h} \cdot \nabla q,
$$

in which $\mathbf{V}_{h}$ is the horizontal wind, and $q$ is specific humidity. Analyzed vertical wind is multiplied by 10 for display purposes. The $332-\mathrm{K}$ contour is red. The right side of the abscissas in Fig. 8 correspond to point $\mathrm{A}$ at the southeast end of the blue lines drawn in Figs. 4g-i. Point B in Figs. $4 \mathrm{~g}-\mathrm{i}$ is located at the other end of each cross section, $500 \mathrm{~km}$ to the northwest of point A. The cross sections were selected so that they were approximately normal to the temperature gradient along the nearsurface front and located near the heaviest rainfall in the principal spiral rainband. Conditionally, symmetrically unstable areas are represented by black dots, which are mostly seen below $500 \mathrm{hPa}$ between 300 and $500 \mathrm{~km}$ from point $A$.

All cross sections contained a maximum in $q_{\text {conv }}$ exceeding $18 \mathrm{~g} \mathrm{~kg}^{-1} \mathrm{~h}^{-1}$ between 1000 and $900 \mathrm{hPa}$. The maximum in $q_{\text {conv }}$ tilted northwestward with height behind the surface front, and $q_{\text {conv }}$ of $6-12 \mathrm{~g} \mathrm{~kg}^{-1} \mathrm{~h}^{-1}$ was present between 600 and $700 \mathrm{hPa}$ in each cross section. To the southeast of the maximum boundary layer $q_{\mathrm{conv}}$, $\theta_{\text {es }}$ isotherms below $900 \mathrm{hPa}$ tilted sharply toward the southeast with height in warm, moist air. To the northwest of the maximum boundary layer $q_{\text {conv }}$, isotherms of $\theta_{\mathrm{es}}$ tilted southeastward with height up to about $950 \mathrm{hPa}$ and then generally northwestward with height above $950 \mathrm{hPa}$. However, at 1200 UTC 8 October, the 334- and 336-K $\theta_{\mathrm{es}}$ contours tilted southeastward with height 


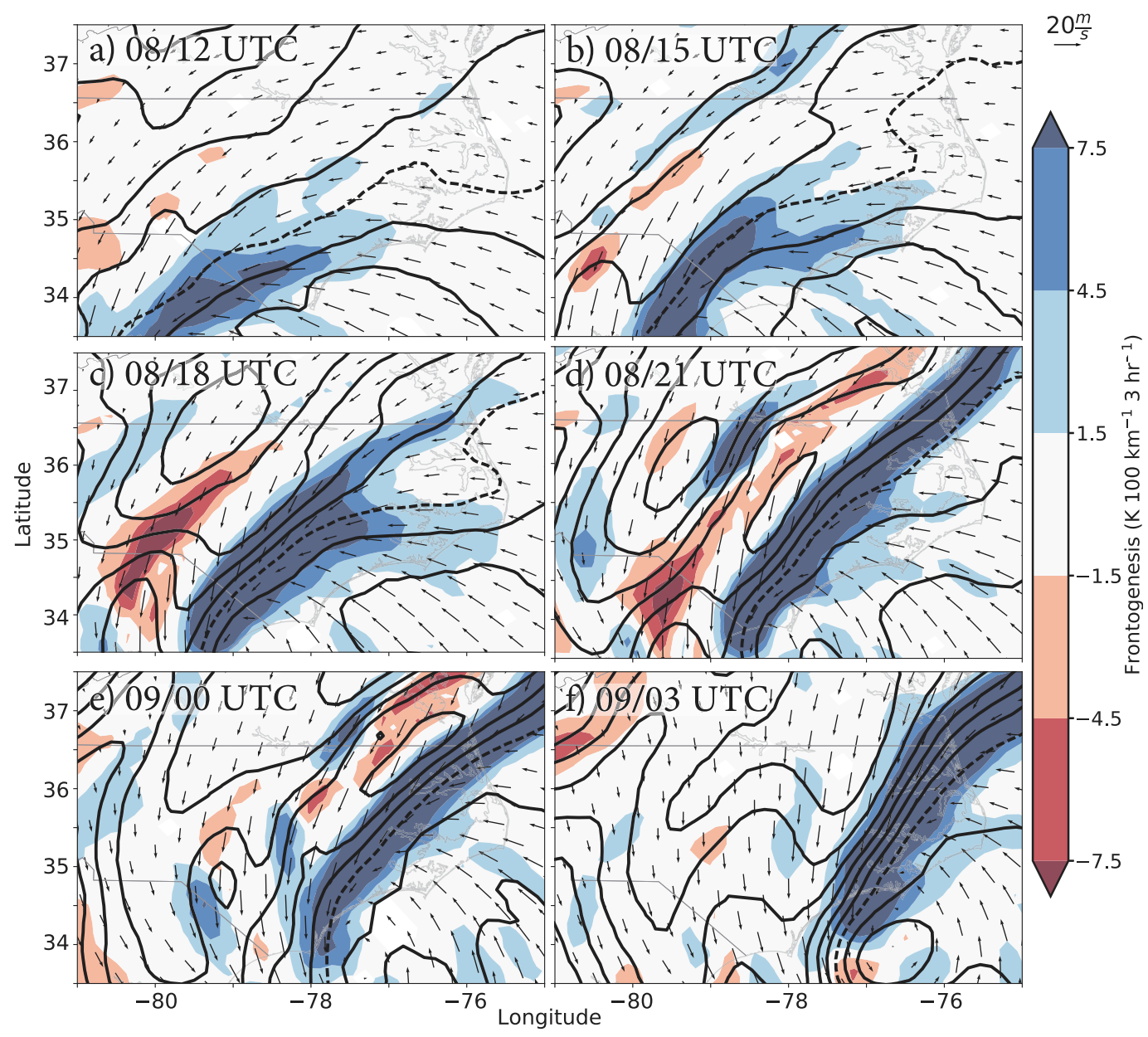

FIG. 7. As in Fig. 4, but zoomed in over eastern North Carolina and displayed every $3 \mathrm{~h}$ from (a) 1200 UTC 8 Oct to (f) 0300 UTC 9 Oct. Potential temperature contour interval is $1 \mathrm{~K}$.

between 700 and $500 \mathrm{hPa}$ around a $\theta_{\mathrm{es}}$ minimum at $500 \mathrm{hPa}$. Also, at $0000 \mathrm{UTC} 9$ October, the 330-334-K isotherms tilted southeastward with height to $950 \mathrm{hPa}$ and then sharply toward the northwest around $900 \mathrm{hPa}$. About $425 \mathrm{~km}$ northwest of point $\mathrm{A}$, the isotherms tilted back toward the southeast up to about $600 \mathrm{hPa}$ as they wrapped around a $\theta_{\mathrm{es}}$ maximum around $800 \mathrm{hPa}$ about $375 \mathrm{~km}$ from point $\mathrm{A}$. The $\theta_{\mathrm{es}}$ isotherms then tilted back toward the northwest around a $\theta_{\mathrm{es}}$ minimum in conditionally symmetrically unstable air above $600 \mathrm{hPa}$ near point $\mathrm{B}$, which was located within the secondary area of the $35+\mathrm{dBZ}$ echo over central VA (Fig. 6e).

Comparison of the three panels in Fig. 8 also reveals the production of a near-surface temperature gradient near and immediately west of the area of maximum moisture convergence. At $1000 \mathrm{hPa}$, the distance between the 332- and the $342-\mathrm{K} \theta_{\mathrm{es}}$ contours shrunk from $165 \mathrm{~km}$ at $1200 \mathrm{UTC}$ to $45 \mathrm{~km}$ at $1800 \mathrm{UTC}$, and $44 \mathrm{~km}$ by 0000 UTC. Below $900 \mathrm{hPa}$, the $342-\mathrm{K}$ contour was always located near the location of maximum $q_{\text {conv }}$.
Contours of lower $\theta_{\text {es }}$ moved eastward relative to maximum $q_{\text {conv }}$, consistent with the evolution of temperature gradients illustrated in Figs. 4 and 7. Figure $8 \mathrm{c}$ also shows the two near-surface regions with a large temperature gradient seen in Fig. 7e: the primary front between 200 and $300 \mathrm{~km}$ from point A, and a second smaller gradient another $\sim 100 \mathrm{~km}$ to the northwest.

\section{Atmospheric instability}

Colle (2003) described how the release of conditional symmetric instability may have intensified rainfall over the northeastern United States during Hurricane Floyd (section 1). How conditional symmetric instability should be calculated remains an unsettled question. Schultz and Schumacher (1999) used the geostrophic wind to compute moist geostrophic $\mathrm{PV}, \mathcal{P}_{g}$, which is defined as

$$
\mathcal{P}_{g}=g \boldsymbol{\eta}_{g} \cdot \nabla \theta_{\text {es }},
$$




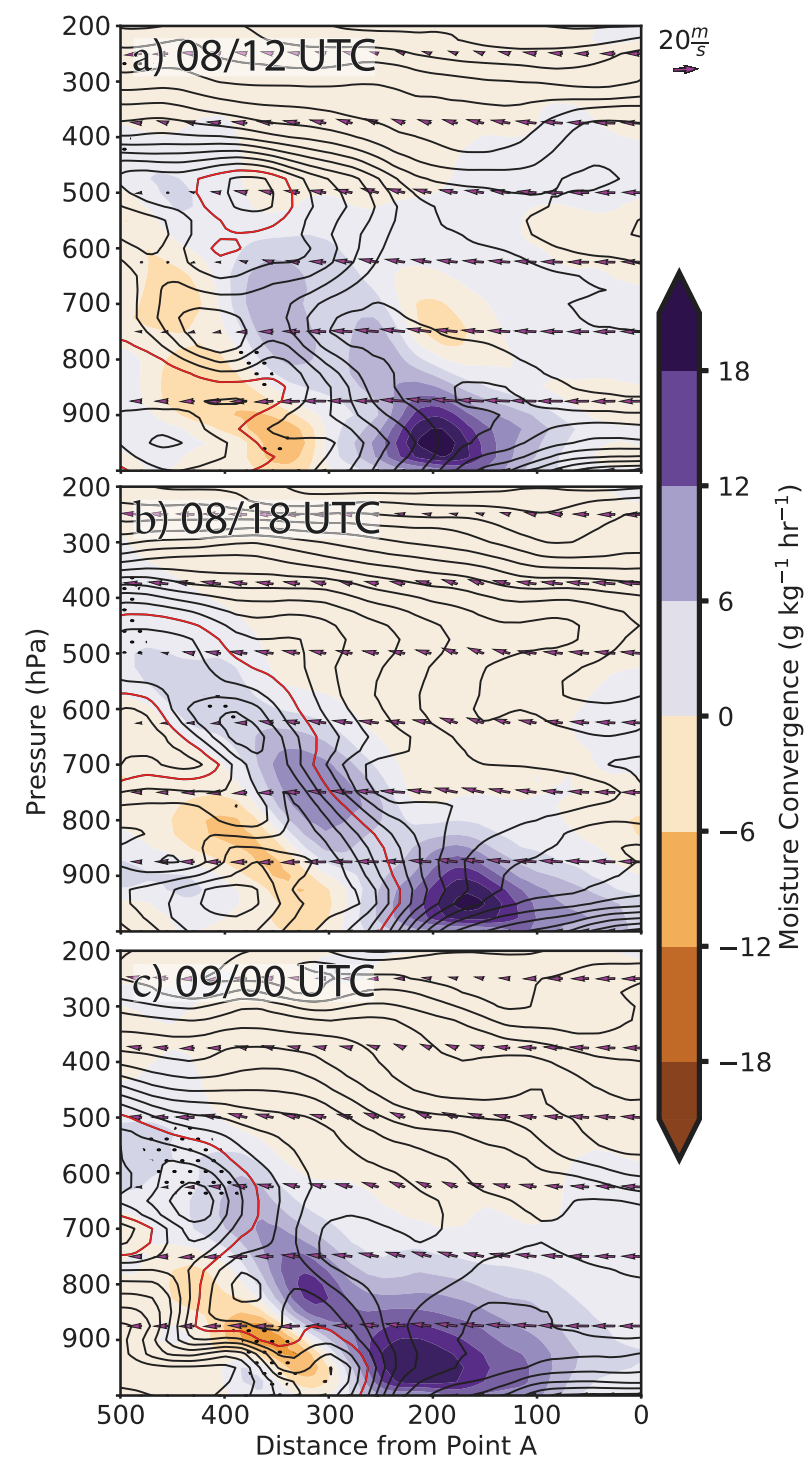

FIG. 8. Southeast-northwest cross sections of moisture convergence $\left(\mathrm{g} \mathrm{kg}^{-1} \mathrm{~h}^{-1}\right.$; shaded), wind along the cross section with vertical velocity multiplied by 10 (vectors), and saturated equivalent potential temperature (K; contours with interval of $2 \mathrm{~K}$ ) every $6 \mathrm{~h}$ from (a) 1200 UTC 8 Oct to (c) 0000 UTC 9 Oct. The red contour denotes the $332-\mathrm{K}$ isotherm. The cross sections correspond to those drawn in Figs. 4g-i. In each panel, point $\mathrm{A}$ is on the right side of the abscissa. Black dots indicate areas of conditional symmetric instability.

in which the variable $g=9.81 \mathrm{~m} \mathrm{~s}^{-1}, \boldsymbol{\eta}$ is the full threedimensional vorticity, $\theta_{\mathrm{es}}$ is the saturated equivalent potential temperature, and subscript $g$ represents the geostrophic part of the subscripted variable.

Others (Gray and Thorpe 2001; Clark et al. 2002; Jurewicz and Evans 2004; Novak et al. 2004, 2006; Schultz and Knox 2007) used the total wind to calculate the moist $\mathrm{PV}, \mathcal{P}$, which is defined similarly to $\mathcal{P}_{g}$, except that the total wind is included:

$$
\mathcal{P}=g \boldsymbol{\eta} \cdot \nabla \theta_{\text {es }} .
$$

Alternatively, the balanced flow-in this case, the nondivergent flow-could be substituted for use in Eq. (5) (Nielsen-Gammon and Gold 2008). Depending on the method utilized, conditional symmetric instability is present when $\mathcal{P}$ is negative or slightly positive and the atmosphere is not conditionally or inertially unstable (Novak et al. 2006). We used both the total wind and nondivergent wind and found only minor differences in calculation of $\mathcal{P}$. Only results using the total wind are displayed herein. We have also checked that the vertical component of $\boldsymbol{\eta}$ is much larger than the horizontal components; therefore, for our purposes, $\boldsymbol{\eta}$ in Eq. (5) can be readily approximated here as $\zeta+f$, in which $f=$ $2 \Omega \sin (\varphi)$ is the Coriolis parameter, and the gradient of $\theta_{\text {es }}$ can be taken on isobaric surfaces. The variable $\zeta$ is the relative vorticity, such that

$$
\zeta=\frac{\partial v}{\partial x}-\frac{\partial u}{\partial y} .
$$

Then, $\mathcal{P}$ takes the form of Ertel PV (a negative sign is introduced since the gradient of $\theta_{\mathrm{es}}$ is taken along the pressure coordinate now), except here we have the moist Ertel PV:

$$
\mathcal{P} \approx-g(\zeta+f) \frac{\partial \theta_{\mathrm{es}}}{\partial p} .
$$

Thus, $\mathcal{P}$ is negative when $\zeta+f$ and $\partial \theta_{\text {es }} / \partial p$ is of the same sign, and herein, we assert that conditional symmetric instability was present during Matthew if $\mathcal{P}$ was negative and $\partial \theta_{\text {es }} / \partial p<0$. Air was conditionally unstable where $\mathcal{P}$ was positive and $\partial \theta_{\mathrm{es}} / \partial p<0$.

Figure 9 depicts the instability of air at $925 \mathrm{hPa}$ (shading) at 3-hourly intervals between 1200 UTC 8 October and 0300 UTC 9 October. Areas where 35+ dBZ radar echoes were present at $2.5-\mathrm{km}$ altitude are outlined by black contours. In this figure, the reflectivity field was degraded to $0.1^{\circ}$ grid spacing. Vectors denote 925-hPa winds. Blue and green shading indicate conditional and conditional symmetric instability, respectively. Air over the ocean or coastal regions of SC, NC, or VA was apparently never conditionally symmetrically unstable. Instead, the low-level warm, oceanic air flowing into the region of frontogenesis from the east and southeast was all conditionally unstable. Before 9 October, no low-level conditional symmetric instability was present within or upstream of the $35+\mathrm{dBZ}$ echo region except over a small area on the southernmost, downstream edge of the $35+\mathrm{dBZ}$ echoes between $79^{\circ}$ and $80^{\circ} \mathrm{W}$. However, at $0000 \mathrm{UTC}$, a corridor of conditional symmetric instability extending from about 

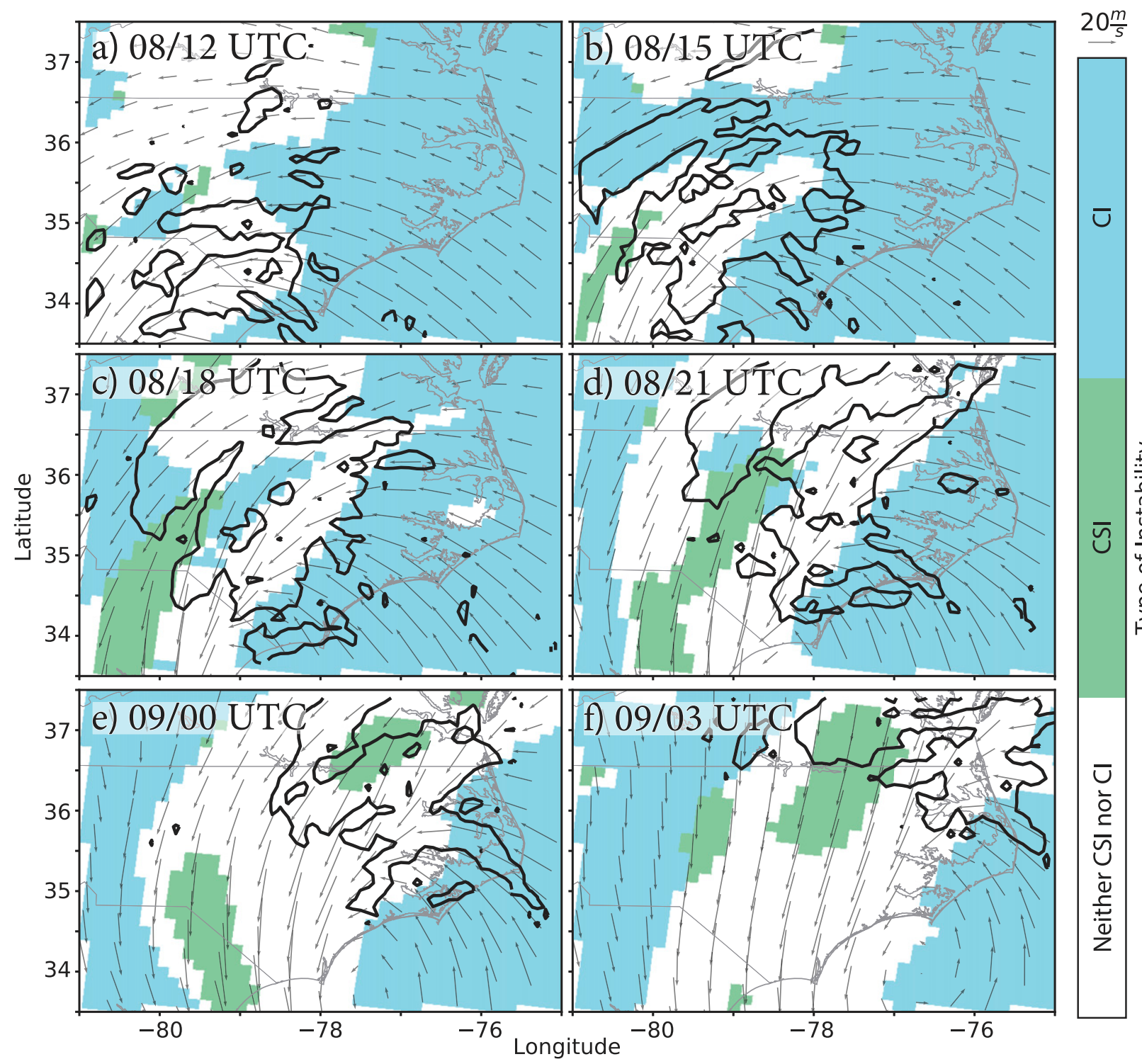

FIG. 9. Maps of atmospheric instability at $925 \mathrm{hPa}$ from (a) 1200 UTC 8 Oct to (f) 0300 UTC 9 Oct. Blue indicates conditional instability, green represents conditional symmetric instability, and white denotes neither conditional nor conditional symmetric instability. 925-hPa wind vectors are displayed. The black contour outlines $35 \mathrm{dBZ}$ radar reflectivity after WSR-88D is interpolated to a $0.1^{\circ}$ grid.

$36.75^{\circ} \mathrm{N}, 77.25^{\circ} \mathrm{W}$ to near $38.5^{\circ} \mathrm{N}, 75^{\circ} \mathrm{W}$ (Fig. 10 ) may have enhanced rainfall intensity in the $35+\mathrm{dBZ}$ echo located southwest or south (i.e., downstream) of the instability. By 0300 UTC, only the area of conditional symmetric instability seen in Fig. 9f remained. Analysis of midlevel (500-700 hPa) instability (not shown) indicates that conditional symmetric instability was also present near or within the secondary $35+\mathrm{dB} Z$ echo region located over central $\mathrm{NC}$ and $\mathrm{VA}$ (around $37^{\circ} \mathrm{N}$, $78^{\circ} \mathrm{W}$ at 0000 UTC) after 1800 UTC 8 October. This instability was located in a region of midlevel moisture convergence approximately $200 \mathrm{~km}$ behind the near-surface front (Fig. 8c). Unsurprisingly, most of the low-level air within the $35+\mathrm{dB} Z$ echo region was neither conditionally unstable nor conditionally symmetrically unstable.

\section{Conclusions}

In October 2016, Hurricane Matthew generated extreme rainfall during its extratropical transition, in some places exceeding $400 \mathrm{~mm}$ total, over a swath that extended from eastern South Carolina (SC) through eastern North Carolina (NC) and southeastern Virginia (VA). Synoptic-scale conditions were favorable (Fig. 3) for the observed left-of-track precipitation distribution 


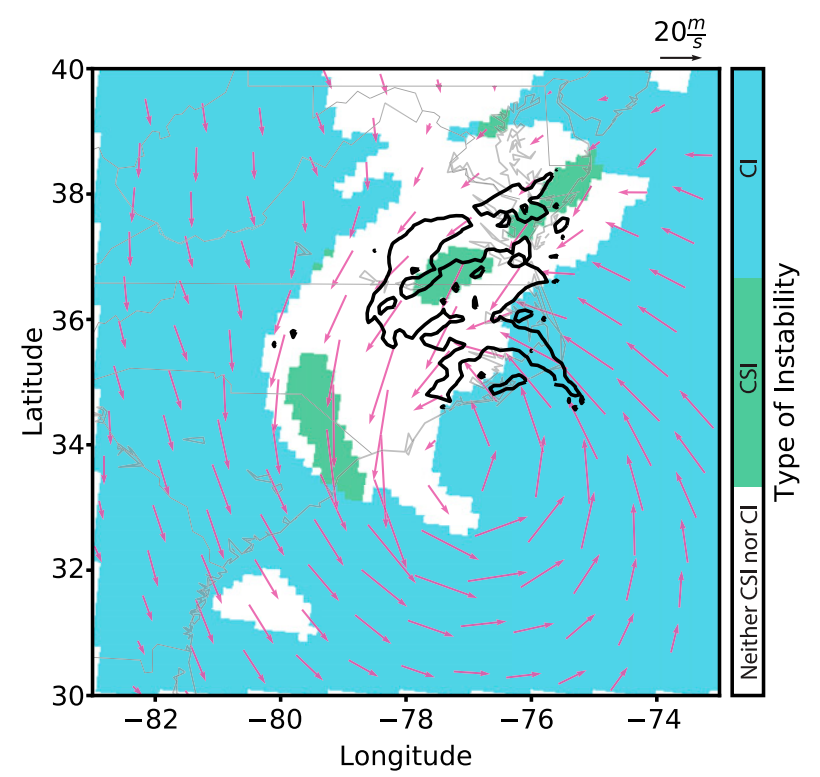

FIG. 10. As in Fig. 9e, but for a larger area spanning $30^{\circ}-40^{\circ} \mathrm{N}$, $73^{\circ}-83^{\circ} \mathrm{W}$.

that has been well documented by prior studies (section 1) of tropical cyclones undergoing extratropical transition along the U.S. East Coast.

Cold-air damming occurred over North Carolina as late as 0600 UTC 8 October (section 3); however, sustained frontogenesis did not begin where the heaviest rainfall occurred until about 1200 UTC (Figs. 4, 7). Therefore, we conclude that, although weak cold-air damming probably occurred prior to Matthew reaching $\mathrm{NC}$, cold-air damming did not impact precipitation totals in NC and VA during Matthew. This conclusion corroborates that of Garcia-Rivera et al. (2016), who studied rainfall patterns over NC during the weaker Tropical Storm Kyle from 2002.

As Matthew moved northeastward along the $\mathrm{NC}$ and SC coastlines, a near-surface front developed about 100 $200 \mathrm{~km}$ inland (Figs. 4, 7), and the corridor of heaviest precipitation corresponded closely in space to the location of the front (Figs. 5, 6). The largest rainfall totals at a given time during Matthew generally occurred at locations where the spiral rainband(s) intersected the frontal boundary, which was approximately normally oriented relative to the spiral rainbands. The northeastward-moving spiral rainbands occurred in areas of large moisture convergence and consisted of discrete oceanic cells that moved inland (counterclockwise around Matthew) then merged into a larger contiguous region of intense convection as the cells approached the surface front. The banded distribution pattern of total rainfall exhibited in Fig. 5a was probably associated with fluctuations in the intensity of rainfall in the principal spiral rainband as it moved northeastward.
In contrast to the simulation of Hurricane Floyd by Colle (2003), we found no evidence of conditional symmetric instability to the east of the near-surface front over eastern SC, NC, and VA. Instead, within and outside of the spiral rainbands, low-tropospheric flow advected warm, moist, conditionally unstable air from the ocean toward the front, which promoted the lift of the air $100-200 \mathrm{~km}$ inland from the coast in NC. Not all of the rainfall in the swath of largest precipitation totals fell within a spiral rainband. A radar echo with reflectivity $\geq 35 \mathrm{dBZ}$ also developed north of the principal spiral rainband along the western edge of the southwest-northeast-oriented axis of near-surface frontogenesis (Figs. 6b-e). A secondary region of frontogenesis farther inland near the NC-VA border at $78^{\circ} \mathrm{W}$ appeared to be related to an intense radar echo that developed over central NC and VA after 1200 UTC 8 October (Figs. 6, 7). Release of midlevel (between 400 and $600 \mathrm{hPa}$ ) conditional symmetric instability may have partially enhanced rainfall there (Figs. 8b,c). After 0000 UTC 9 October, the inland temperature gradient merged with the coastal front (Figs. 7h-i), thereby increasing the temperature gradient at the coast by 0300 UTC. This coincided with invigoration of precipitation in the spiral rainband over NC and VA at that time (Fig. 6f).

Not detailed in this study are the polarimetric and three-dimensional characteristics of radar echoes within Matthew. We noted during the course of our study that the polarimetric signature of discrete convective radar echoes embedded within spiral rainbands evolved as they moved closer to shore. While we have not investigated this phenomenon in great detail, we speculate that different aerosol composition or concentration over the ocean and land may explain our observation. Also of particular interest to the authors are the kinematics of a near-coastal band of extreme rainfall (Fig. 6c) that persisted just along the North Carolina coast on 8 October. Although the precipitation distribution of Matthew was generated by mechanisms similar to that of other cyclones undergoing extratropical transition, the unique track of Matthew's center parallel to but just offshore the U.S. East Coast provides previously unavailable opportunities to utilize dual-polarimetric WSR-88D data and explore the evolution of convection over several days as the hurricane weakened and transitioned into a post-tropical cyclone.

Acknowledgments. Comments from three anonymous reviewers and Editor D. Schultz were instrumental in improving upon early versions of this article. S. Powell was supported by a NOAA Climate and Global Change Postdoctoral Fellowship, sponsored by UCAR's Cooperative 
Programs for the Advancement of Earth System Science, and Research Initiation Program funding from the Naval Postgraduate School. M. Bell was supported by Grant AGS-1701225 from the National Science Foundation.

\section{REFERENCES}

Atallah, E. H., and L. F. Bosart, 2003: The extratropical transition and precipitation distribution of Hurricane Floyd (1999). Mon. Wea. Rev., 131, 1063-1081, https://doi.org/10.1175/1520-0493 (2003) $131<1063$ :TETAPD $>2.0$. CO; 2

$\longrightarrow,-$, and A. R. Aiyyer, 2007: Precipitation distribution associated with landfalling tropical cyclones over the eastern United States. Mon. Wea. Rev., 135, 2185-2206, https://doi.org/10.1175/ MWR3382.1.

Bailey, C. M., G. Hartfield, G. M. Lackmann, K. Keeter, and S. Sharp, 2003: An objective climatology, classification scheme, and assessment of sensible weather impacts for Appalachian cold-air damming. Wea. Forecasting, 18, 641-661, https://doi.org/10.1175/ 1520-0434(2003)018<0641:AOCCSA > 2.0.CO;2.

Bell, G. D., and L. F. Bosart, 1988: Appalachian cold-air damming. Mon. Wea. Rev., 116, 137-161, https://doi.org/10.1175/1520-0493 (1988) $116<0137:$ ACAD $>2.0 . C O ; 2$.

Benjamin, S. G., and Coauthors, 2016: A North American hourly assimilation and model forecast cycle: The Rapid Refresh. Mon. Wea. Rev., 144, 1669-1694, https://doi.org/10.1175/MWR-D-15-0242.1.

Bosart, L. F., and D. B. Dean, 1991: The Agnes rainstorm of June 1972: Surface feature evolution culminating in inland storm redevelopment. Wea. Forecasting, 6, 515-537, https://doi.org/ 10.1175/1520-0434(1991)006<0515:TAROJS $>2.0$. CO;2.

Clark, J. H. E., R. P. James, and R. H. Grumm, 2002: A reexamination of the mechanisms responsible for banded precipitation. Mon. Wea. Rev., 130, 3074-3086, https://doi.org/ 10.1175/1520-0493(2002)130<3074:AROTMR>2.0.CO;2.

Colle, B. A., 2003: Numerical simulations of the extratropical transition of Floyd (1999): Structural evolution and responsible mechanisms for the heavy rainfall over the northeast United States. Mon. Wea. Rev., 131, 2905-2926, https://doi.org/10.1175/ 1520-0493(2003)131<2905:NSOTET > 2.0.CO;2.

Croke, M. S., 2005: Examining planetary, synoptic, and mesoscale features that enhance precipitation associated with landfalling tropical cyclones in North Carolina. M.S. thesis, Dept. of Marine Earth and Atmospheric Sciences, North Carolina State University, $231 \mathrm{pp}$.

Evans, C., and Coauthors, 2017: The extratropical transition of tropical cyclones. Part I: Cyclone evolution and direct impacts. Mon. Wea. Rev., 145, 4317-4344, https://doi.org/10.1175/ MWR-D-17-0027.1.

Garcia-Rivera, J. M., Y.-L. Lin, and Y. Rastigejev, 2016: Tropical Storm Kyle (2002) and cold-air damming: Their interactions and impacts on heavy rainfall in the Carolinas. Meteor. Atmos. Phys., 128, 347-372, https://doi.org/10.1007/s00703-015-0421-1.
Gray, S. L., and A. J. Thorpe, 2001: Parcel theory in three dimensions and the calculation of SCAPE. Mon. Wea. Rev., 129, 1656-1672, https://doi.org/10.1175/1520-0493(2001)129<1656: PTITDA $>2.0 . \mathrm{CO} ; 2$

Jones, S. C., and Coauthors, 2003: The extratropical transition of tropical cyclones: Forecast challenges, current understanding, and future directions. Wea. Forecasting, $\mathbf{1 8}$, 1052-1092, https://doi.org/10.1175/1520-0434(2003)018<1052: TETOTC $>2.0 . \mathrm{CO} ; 2$.

Jurewicz, M. L., Sr., and M. S. Evans, 2004: A comparison of two banded, heavy snowstorms with very different synoptic settings. Wea. Forecasting, 19, 1011-1028, https://doi.org/10.1175/ WAF-823.1.

Lackmann, G. M., and W. M. Stanton, 2004: Cold-air damming: Physical mechanisms, synoptic settings, and model representation. Preprints, 20th Conf. on Weather Analysis and Forecasting/16th Conf. on Numerical Weather Prediction, Seattle, WA, Amer. Meteor. Soc., 18.6, https://ams.confex.com/ams/ 84Annual/techprogram/paper_73411.htm.

Nielsen-Gammon, J. W., and D. A. Gold, 2008: Dynamical diagnosis: A comparison of quasigeostrophy and Ertel potential vorticity. Synoptic-Dynamic Meteorology and Weather Analysis and Forecasting, Meteor. Monogr., No. 33, Amer. Meteor. Soc., 183-202.

NOAA, 2018a: Surface analysis 21Z Sat Oct 8 2016. NOAA, accessed 26 November 2018, https://www.wpc.ncep.noaa.gov/ $\mathrm{html} / \mathrm{sfc}$-zoom.php? $\mathrm{h}=21 \& \mathrm{y}=2016 \& \mathrm{~m}=10 \& \mathrm{~d}=08$.

_ 2018b: WPC QPF Archive. NOAA, accessed 26 November 2018, https://www.wpc.ncep.noaa.gov/archives/qpf/get_qpf_images.php.

Novak, D. R., L. F. Bosart, D. Keyser, and J. S. Waldstreicher, 2004: An observational study of cold season-banded precipitation in northeast U.S. cyclones. Wea. Forecasting, 19, 993-1010, https://doi.org/10.1175/815.1.

— J. J. Waldstreicher, D. Keyser, and L. F. Bosart, 2006: A forecast strategy for anticipating cold season mesoscale band formation within eastern U.S. cyclones. Wea. Forecasting, 21 , 3-23, https://doi.org/10.1175/WAF907.1.

Petterssen, S., 1936: Contribution to the theory of frontogenesis. Geofys. Publ., 11 (6), 1-27.

Rackley, J. A., and J. A. Knox, 2016: A climatology of southern Appalachian cold-air damming. Wea. Forecasting, 31, 419432, https://doi.org/10.1175/WAF-D-15-0049.1.

Schultz, D. M., and J. A. Knox, 2007: Banded convection caused by frontogenesis in a conditionally, symmetrically, and inertially unstable environment. Mon. Wea. Rev., 135, 2095-2110, https:// doi.org/10.1175/MWR3400.1.

_ , and P. N. Schumacher, 1999: The use and misuse of conditional symmetric instability. Mon. Wea. Rev., 127, 2709-2732. Corrigendum, 128, 1573.

Stewart, S. R., 2017: Tropical Cyclone Report: Hurricane Matthew (28 September-9 October 2016). NHC Rep. AL142016, NOAA/NWS/NCEP/National Hurricane Center, 96 pp., https://www.nhc.noaa.gov/data/tcr/AL142016_Matthew.pdf. 